Gaziantep University, cildirimegantep.edu.tr, Gaziantep-Turkey

DOI $\quad$ http://dx.doi.org/10.12739/NWSA.2019.14.3.D0238

ORCID ID $0000-0003-0348-2992$

\begin{tabular}{l|l}
\hline CORRESPONDING AUTHOR & Ceren Yıldırım
\end{tabular}

\title{
BAŞLANGICA DÖNEN MODERN: MADOURA ATÖLYESİ ÜRETIMLERI İLE PİCASSO
}

\section{Öz}

Yirminci Yüzyıl ressamlarının çağdaş yorumlarına kadar, seramik, Batı dünyasında geleneksel kap olma özelliğinden ötürü zanaat sayılarak minör sanatlar arasında yer almıştır. ìlk defa Picasso seramiğin özünde yer alan iç boşluk kavramını, işlevselliğinden sıyırarak modern bir dile kavuşturur. Eserlerinde, çağdaşı sanatçıların yorumlarından farklı olarak form ve resim birbirini oluşturur, dönüştürür. Bir kap olmaktan daha fazlasını ifade eden bu zanaat, metafor oluşturduğu için bir sanat türüdür. Picasso kap formlarındaki metaforları görünür kılarak Klasik Seramik Sanatının oluşum mantığını kullanmıştır. Geleneği yeni bir dille yorumlar. Picasso'nun gelenek ile kurduğu bu bağ, dönemi ve kültürü içerisinde, bu dönem ve kültüre verdiği bir yanıttır. 3500 esere imza atarak, toprak, doğa, Doğu, primitif, geleneksel ve zanaat kavramlarını yüceltmiştir.

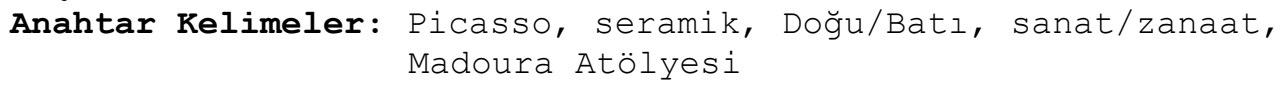

\section{A MODERN; RETURNING TO THE ROOTS: PICASSO AND HIS CREATIONS IN MADOURA WORKSHOP}

\section{ABSTRACT}

The art of ceramics was considered as a minor craft due to the functionality of the final product as a common household container. Only through contemporary interpretations such as by Twentieth Century painters, ceramics has re-gained attention. For the first time, Picasso released ceramics from the burdens of interior space concept or functionality to acquire a modern presentation. Compared to his contemporaries, he created forms and images that complement each other. Becoming more than a container this approach is considered a form of art because it creates metaphor. Picasso used the metaphor of vessel forms of his logic which led formation of classic ceramic art by making it visible. He codes traditional comments in a new language. Picasso created a connection that ties tradition and culture in the period, and that period is a response to culture. By creating 3500 pieces of work, he glorified earth, nature, East, primitive, tradition and craft concepts.

Keywords: Picasso, Ceramic, East/West, Art/Craft, Madoura Workshop 


\section{GIRIŞ (INTRODUCTION)}

Hammaddesi kil olup, elle, kalıpla ya da torna ile biçimlendirilen ve ardından fırınlanarak dayanıklı hale getirilen her tür objeye seramik diyoruz (Sözen ve Tanyeli, 1986: 213). Diğer bir tanıma göre, su ile temas etiğinde plastik özellik kazanarak şekillendirilebilen, kurutulduğunda formunu koruyan ve pişirildiğinde mukavemet kazanan inorganik toprak malzemelere denir (Bayazit ve Işık, 2012:892). Seramik kelimesi köken olarak Yunanca'daki keramos'tan gelir. ${ }^{1}$ Yunanca'da keramos boynuz demektir. Antik Yunan geleneksel törenlerinde şarap ve benzeri içecekler, hayvan boynuzlarından üretilmiş kaplardan içilirdi. Keramoslar yerlerini seramik kaplara bıraktıktan sonra da bu kelime kullanılmaya devam etmiştir (Özen, 1993:3). Seramiğin doğuşu dendiğinde ilk akla gelen, ilkel insanın, işlevsel kap gereksinimidir: "(b)ugün Seramik dediğimiz sanat, ilkel insanın kap gereksinmesi ile ortaya çıkan, mütevazi bir kap sanatıdır" (Galatalı, 1985:68). Bununla birlikte kilden üretilmiş hayvan ve idol heykelciklerinin ortaya çıkışı, kap-kacağın ortaya çıktığı tarım kültüründen daha eskidir² (Görsel 1). Paleolitik Dönemde taş ya da fildişinden üretilen doğurganlık sembolleri, bereketlilik kültünde can veren toprak ana inanışının gelişimi ile topraktan imal edilmeye başlanmıştır.3 M.Ö. 8000'den itibaren başlayan Neolitik'in Çanak Çömleksiz ilk iki bininde kilden küçük figürler ve pişirmeksizin kapkacak üretimi yapılmıştır (Başgelen, 2006:114). Sanatın henüz var olmadığı, büyü olduğu, tarihöncesi devirlerde5, kilden üretilmiş idol heykellerin seramik sanatı sınıfına mı yoksa heykel sanatı sınıfına mı dahil edilmesi gerekliliği de anlamsız kalacaktır. Bu tür ayrımlar ancak yerleşik hayatın getirisi olan sınıflı toplumla birlikte, iş kolları ayrımının oluşumu sonucunda ortaya çıkmıştır. Sanatın sınırlarının eridiği günümüzde de benzer ayrımlar önem derecesini yitirmiştir. Çă̆ımızda seramik sanatı, heykel ve resim alanları ile etkileşimini sürdürmektedir. Çevik'e göre eski ve aynı zamanda çağdaş olan bu disiplin, heykel sanatının biçim, resim sanatının da yüzeye

\footnotetext{
1 Murat Bayazit ve İskender Işık ise "Geçmişten Günümüze Çini Sanatı ve Kütahya Çiniciliği" adlı çalışmalarında seramik kelimesinin Yunanca'da kil anlamına gelen keramikos kelimesinden geldiğini söylemektedirler (2012: 892) Antik Yunan mitolojisine göre Ceramus Képapos, (Kerameikos) Dionysos ile Areiadne'nin oğlu olan çömlekçilik tanrısının adıdır. Antik Çağda Kerameikos'un sanatını icat ettiği yer olan Muğla-Milas arasındaki bölgeye isim olarak verilmiştir.

2 M.Ö. 6000 tarihli Çatalhöyük buluntuları tarihteki ilk seramikler olarak anılırken son arkeolojik buluntular insanoğlunun henüz yerleşik yaşama geçmezden önce yani kap kacak yapmaya başlamazdan önce, kilden idol heykelcikler yaptığını ortaya koymuştur. Kurutulmuş, ya da düşük ısıda pişirilmiş toprak idollerin en eski tarihli olanları Mezolitik Dönem'e (M.Ö. 14.000-9000) aittir. "Mezolitik/Epipaleolitik Cağ'da üç boyutlu insan betimlemeleri, Anadolu dışında birçok örnek olmasına karşın, Anadolu'da bu döneme ait üç boyutlu insan biçimli betimlere çok az rastlanılmıştır. Bunun en önemli nedeni bu döneme ait arkeolojik kazıların çok az olmasıdır. Ancak yeni kazılarda bu döneme ait insan figürinleriyle karşılaşılması da muhtemeldir. Örneğin Kahramanmaraş'ın Direkli Mağarasında son yıllarda bulunan kilden kadın figürini Anadolu'da bu çağa ait tek örnektir" (Yücel, 2018:234).

3 Çağatay Yücel, "Tarih Öncesi İnsan Biçimli Figürinler Hakkında Genel Bir Değerlendirme" isimli makalesinde Van Buren'den alıntı yaparak tarih öncesi figürinlerde taş yerine toprağın tercih edilme nedenini ekonomik olması ile açıklar (232). Ancak ataerkil düzenden daha geriye, ana erkil düzene gidecek olursak; bu kültürde toprağın tercih edilişi kadın-toprak-bereketlilik kültünden ötürü ekonomik nedenlerin ötesinde olmalıdır. Farklılığı açıklamada Batı'nın en yakın tarihli anaerkil düzeni örneğine bakılabilir: "Yunanistan'da bir kadın çömlekçiye hiçbir zaman rastlanmazken Girit medeniyetinde, balçık pişirme yöntemini kadınların bulduğu, hiçbir kuşkuya yer bırakmayacak biçimde anlaşılmaktadır (Turani, 2007:132). Neolitik Çağ'ın tarım kültürlerinde çömlekçilik bütünüyle kadınlara özgü bir uğraştır (Güner, 1988:8) .

4 Pişirme konusunda farklı bir kaynak olarak Güner, Anadolu'da Yaşamakta olan İkel Çömlekçilik adlı eserinde Paleolitik Döneme tarihlenen seramik pişirmede kullanılmış bir çukurun varlığından bahseder (1988:9).

5 "(i) lkel toplumlarda ne bilim vardır, ne de sanat; yalnızca büyü vardır" (Thomson, 1998:25).
} 
ait tüm sorunlarını ve çözüm olanaklarını bünyesinde barındırır (2010:44). Bu nedenle seramik sanatı, resim, heykel ve grafik gibi temel sanat alanlarından kopartılmamalıdır da. Kopartılırsa bu onu malzeme hudutlarına hapseder. Çamur, amaç olmaktan çıkartarak malzeme gerecine indirgendiğinde, vasıta olarak kullanılan diğer malzemelerle aynı kefeye konmuş olur. Bu şekilde seramik sanatı malzemeyle sınırlı kalan bir zanaattan ileri gidemeyecektir (2015:107).6

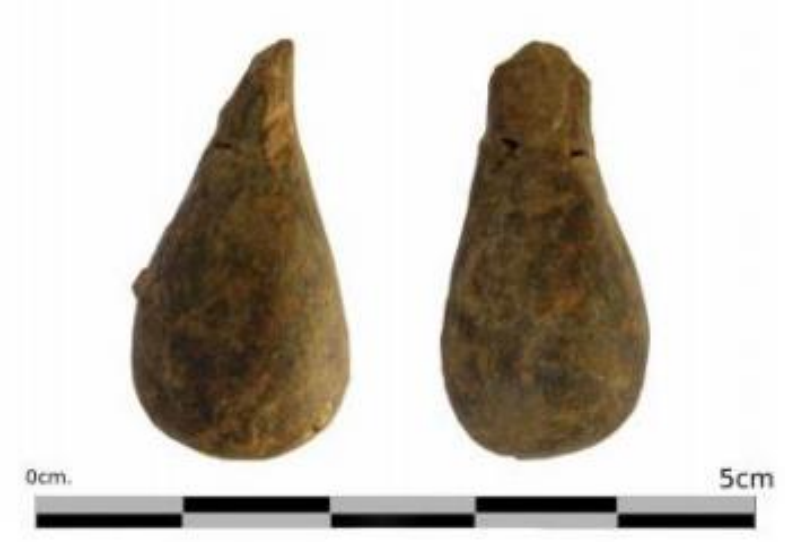

Görsel 1. Mezolitik Dönem pişmiş toprak İdol, Kahramanmaraş Direkli Mağarası (Visual 1. Mesolithic terracotta idol Kahramanmaraş Direkli Cave)

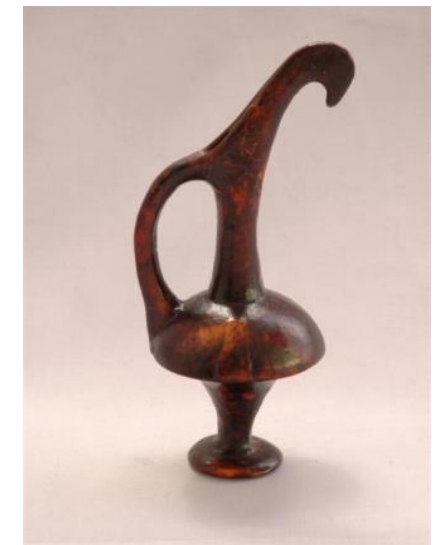

Görsel 2. Hitit uygarlığı gaga ağızlı testi M.Ö.1700, (Visual 2. Hittite civilization, beak mouth test B.C. 1700)

\section{2. ÇALIŞMANIN ÖNEMI (RESEARCH SIGNIFICANCE)}

Bu çalışmada ressam bir seramik sanatçısı Pablo Picasso'nun (1881-1973) eserleri konu edilmiştir. Çalışmanın amacı modern seramik sanatının doğuşunda etkili olmuş 20. yüzyıl ressamlarından Picasso'nun, konu bağlamındaki ayrıcalıklı yerini tartışmaktır. Picasso seramik eserlerinin, çă̆daşlarından farklılaşan temel özelliği, bu sanatın geçmiş geleneği ile kurduğu derin bağdır. Sanatçı henüz gençken primitif kültürlerden etkilenmeye başlamış; resimlerindeki ilk kübik formlar da bu etkiler sonucunda ortaya çıkmıştı. Geç döneminde kurduğu primitif kültür bağı ise daha doğrudan, yaşayarak kurulmuş bir bağdır. Sanatçı için ilk insanın var olduğu çă̆larda üzerine kurgular geliştirdiği toprak ve su, ateş, hava temel elementlerini kullanarak sanat üretmek adeta kaynağa dönüş anlamı taşımıştır. John Berger, Picasso'nun sanatındaki primitif iç tepiyi sanatçının psikolojisini irdeleyerek ele alır. Georges Ramie birebir tanıklığı ile Picasso'nun seramik üretirkenki coşkun ruh halini bize aktarır. Tüm okumalarımız ve gözlemlerimiz sonucunda anlarız ki Picasso'nun seramik sanatında bulduğu güç, doğa ile dostluğu deneyimleyen, en eski geleneğe bağlı insanlarınkine benzer bir tutumdur. Oyuna dayalı bir buluş heyecanı, taze ve katışıksız olarak, bu doğal malzemeden akıcı şekilde bizlere ulaşır. Picasso'nun geç döneminde cezbesine kapıldığı seramik sanatı, olgun bir zihnin saf olana dönüşü olarak değerlendirilebilir.

\footnotetext{
6 Avşar bu açıklamasında Batı Sanatı'nda zanaatın sanattan aşağı bir seviyede olduğu gerçeğinden hareket etmiştir. Doğu sanatlarında zanaat zaten sanat olduğundan aralarında bir değer hiyerarşisi yoktur. Batı sanat söylemi içerisinde kast edilen sanatın men ettiği basmakalıp olma, yaratıcı olamama durumlarıdır. Oysa örneğin "Doğu" sanatları içerisinde İslam estetiğine göre zanaatçılık yaratıcılıktan uzak bir basmakalıpçılık anlamına gelmez. İslam estetiğinde sınırlar çizilerek içerisinde hareket edilmesi, onun yeterince anlaşılamamasının da nedeni olmuştur. Yoksa bu estetiğe göre yaratım her an devam etmektedir (demdedir). Dolayısıyla her eser özgün yaratıcılıktadır.
} 


\section{YÖNTEM (METHODOLOGY)}

Çalışmada yöntem olarak Picasso seramik eserleri ile primitif, zanaate dayalı gelenekselci, Klasik, çağdaş dekoratif ve Picasso'nun çağdaşı ressamlarca ürfetilen seramik eserler karşılaştırılıp yorumlanmıştır. Tarih, estetik, sanat felsefesi, sanat psikolojisi, sanat sosyolojisi ve sanat tarihi kuramları bazında ele alınan araştırmada betimlemeci yöntem kullanılmıştır.

\section{4. ÇAĞDAŞ SERAMIK SANATININ DOĞUŞU (THE BIRTH OF MODERN CERAMIC)}

Sanatın ne olduğu sorusu yaşam ve toplum değiştikçe değişime uğramıştır. Seramik adı altındaki üretimlerin geleneksel el sanatları içerisindeki bir zanaat türü mü olduğu; endüstriyel seri üretim ya da sanatsal tasarım ağırlıklı işlevsel kaplar mı olduğu; kap olduğu halde seyirlik obje mi olduğu7; seramik heykeller ya da hazır nesne kavramsal sanat mı olduğü; gelenekselden sentezlenen modern sanat üretimi mi olduğu gibi ve benzeri sorular, bir sınıflandırma yapmak gerekliliğini doğurmuştur. Bu sınıflandırma özellikle Doğu/Batı kültür ayrımlarındaki sanat/zanaat tartışmaları bağlamında da önem arz etmiştir. Atilla Galatalı bu sınıflandırmayı:

- Klasik seramik ve modern çömlekçilik sanatı;

- Endüstriyel seramik;

- Soyutlayıcı çă̆daş seramik; şeklinde yapar (1985:69).

Kullanım özelliğinin yanı sıra sanatsal değer de taşıyan üretimlere Klasik Seramik denir. Galatalı'ya göre seramik sanatı klasik olgunluğuna İlk Çağda erişmiştir. En güçlü dönemini Hitit, Frig ve Asur Uygarlıklarında yaşamıştır. Seramik yüzey, organik gerçeğini bu eserlerdeki kadar başka hiçbir dönemde yaşayamamıştır (Görsel 2). Bu muhteşem sanat İlk Çă̆ın kapanışıyla birlikte özgün vasıflarını yitirmeye başlamıştır. Ehil olmayan kişilerin elinde gerçekleşen niteliksiz çoğaltımlar seramiğin çöküşünü getirmiştir. Seramik sanatının hâlâ "zanaat" sayılmasının altında yatan tarihsel gerçek de budur (1985:69). 20. yüzyılda seramik yüzeyin plastisitesi yeniden keşfedilmiştir. Bu keşifle seramik, çă̆daş bir sanat olarak tekrar doğmuştur. Modern üretimler de kendi içinde:

- Klasik-Modern Sentezci;

- Soyut-Özgün Form;

- Seramik Heykel olarak üç ana grupta incelenebilir (Uludağ, 1997:146).

Ağatekin'e göre Çağdaş Seramik Sanatının başlangıcı tek bir kişi ya da bir grup sanatçı topluluğuna indirgenemez. Bu bir oluşum sürecidir ve sanayi tipi seri üretime tepki olarak doğan Arts and Crafts hareketi ile başlamıştır. Art-Deco hareketi ile devam etmiştir (2002:1). Ardından sanatçı-çömlekçi kavramını ortaya atan Bernard Leach (1887-1979) ile modern anlamda seramik tasarımı doğmuştur (Tizgöl, 2008:90). Tasarım alanında Bauhaus Ekolü'nün özgün ve zengin üretimlerini de saymak gerekir (İnal, 2006:107). İşlevselliği devre dışı bırakarak klasik-modern sentezi oluşturan ilk seramikçiler ise Picasso ve çağdaşı 20. yüzyıl ressamlarıdır (Alkan, 1999:5). Yukarıda saydığımız, işlevsel ürün tasarımının yeni sunum arayışlarının yapıldığı dönem ile ilk soyut ve ekspresif çalışmaları gerçekleştiren Bernard Leach ekolü seramikçileri arasında yer alırlar (Şölenay ve Özer, 2013:35). Yirminci Yüzyıl Paris Ekolü ressamlarından Paul Gauguin, seramiklerinde ilkel dili vahşi bir hamlıkla ele geçirmede başarılı olmuştur. İlkel köklere en çok geri gidebilen bir diğer

\footnotetext{
7 Alev Ebuziya örneğinde olduğu gibi

8 Dada ve sonrasında seramiğin işlevsellik ilkesini dışlayan bazı sanatçılar, klasik anlamda seramik üretiminden ve seramik heykelden kurtulma çabasında olmuşlardır.
} 
modern, Akdeniz seramik diline hakim olan Pablo Picasso'dur. Gelenek ile moderni sentezlemede 3500 özgün tasarıma imza atmıştır. Picasso'nun çağdaşı modernler içerisinde seramik üreten diğer ressamlar arasında Georges Braque, Joan Miro, Fernand Leger, Henry Matisse, Raoul Dufy, Van Dongen, Wassilly Kandinsky kendi resim dillerini seramik üzerine tatbik ederken, Vilademir Tatlin, Kasimir Malevich, Lucio Fontana ve Asger Jorn daha ziyade seramikte kendi özgün form dillerini aramışlardır. Bunun dışında Rene Buthaud, Galileo Chini, Gio Ponti, Anthony van Der Leck ve Rudy Autio seramikçi olup eserlerini resimlendiren önemli sanatçılar arasında gösterilebilir. Alexander Archipenko, Elie Nadelman ve Isamu Noguchi ise Paris avangardını Amerika'ya taşımıs, seramik heykel alanında eserler vermiş isimler arasında sayılabilir (Alkan, 1999:3). Türk ressamlardan seramik eserler üretmiş olan sanatçılarımız arasında Abidin Dino, Bedri Rahmi Eyuboğlu, Burhan Uygur, Devrim Erbil, Hanefi Yeter, Cihat Burak, İgi Adalan ve Bilgehan Uzuner ilk akla gelen isimlerdir (Gökkaya, 2013:27-39).

Yaz tatillerini Cannes'da geçiren Picasso Vallauris kasabasını ilk defa 1946 senesinde 65 yaşındayken, şair dostu Paul Eluard'la birlikte ziyaret eder. İkinci Dünya Savaşı'ndan kaçarak buraya sığınan, Fransız ve diğer ülkelerden gelen çok sayıdaki seramikçi, ürünlerini her yıl düzenledikleri sergilerle Riviera koleksiyonerlerinin beğenisine sunmaktaydılar (Ramie, 1985:7). Festivali duyan Picasso sergiyi izlemeye gelir. Özellikle Madoura Atölyesi üretimleri ile ilgilenir, eserlerin yaratıcılarını sorar. Suzanne ve Georges Ramie ile tanışarak, Madoura Atölyesi'nde o gün bir faun başı, iki boğa şekillendirir ve akşam Vallaruris'tan ayrılır. Ertesi yaz Madoura çömlek evini tekrar ziyarete gelir. Bu sefer içindeki dürtüye daha fazla hakim olamayarak, atölyede kendisi için ayrılan yere yerleşir ve üretmeye başlar. Farklı tekniklerle tanıştıkça önünde yeni ufuklar açılır. En ufak bir keşif, sonu gelmez yaratıcılıklara vesile olur. Bu şekilde yirmi senede binlerce eser üretir. Picasso'nun açtığı yoldan pek çok sanatçı geçer. Ayrıca çalıştığı atölye onu ziyarete gelen sanatçı dostlarının da (G. Braque, M. Chagall, H. Matisse, J. Miro, M. Utrillo, Abidin Dino, L. Aragon, Cocteau, P. Eluard, C. Chaplin, J. Prevert, Le Corbusier, Arthur Rubinstein, llya Ehrenbourg, André Malraux) sayesinde evrensel bir akademiye dönüşür (Çil, 1997:10) .

\section{GELENEĞE DÖNÜŞ-GELECEĞİ KURMAK} (RETURNING TO THE TRADITION-CONSTRUCTING OF THE FUTURE)

Seramik, üretildiği coğrafyanın kültürel kimliğini en doğrudan yansıtan sanat disiplinidir. Kendine özgü üretim teknikleri sebebiyle insan doğasına yakındır (Gökkaya, 2013:26). Nissen'e göre en çok duyu ile kuşatılmış olandır: çanak çömleği biçimlendirme olanakları o kadar çeşitlidir, bu olanaklar dış etkileri önceden saptanmış kalıplara o denli az bağlıdır ki, seramik, insan ürünleri içinde en çok 'duyu ile donatılmış olanlar' arasında sayılır. Duyu sahibidir, çünkü bireyselleşme, belirli bir eğilimi izleyerek ya da yeni bir yaratıyı ortaya koyarak kotarma eğilimleri, çanak çömlekte, öteki türlerde olduğundan daha çabuk ortaya çıkar. Malzemenin kırılganlığı üretim artışına neden olurken, zamana ve doğa şartlarına karşı dayanıkıılığı üslupsal gelişim ya da dönüşüm aşamalarının takibini arkeoloji açısından kolaylaştırır (2004:33-34).9 Seramiğin gelişimi, toplumların

\footnotetext{
Örneğin resim örneklerinin mevcut olmadığı geçmiş dönemlere dair resim sanatını seramik kaplardan öğrenmekteyiz. Seramikteki kap kacak süslemesini resimle ilgili sorunlar arasına katmak, önemli resim örneklerinin bulunamadığı ya da henüz başlamamış
} 


\begin{abstract}
sosyo-kültürel ve ekonomik evreleri ile paralellik gösterir (Mutlu, 2007:72). Dünyanın neresinde olursa olsun bölgeye ait biçim ve dekoru taşırlar (Alkan, 1999:1). Bu nedenle Herbert Read'in de dediği gibi bir milletin sanatını ve duyarlılığını takipte en geçerli ölçüt, ortaya koyduğu seramikleridir. Ortaya çıktığı "Anadolu'da pişmiş toprağın kullanımı, seramik sanatı ve üretimi anlamında yaklaşık olarak on bin yıllık bir geçmişe sahiptir" (Yücel, 2018:231). Doğduğu günden bu yana seramik, kap olma, işlevsellik özelliğini sürdürmüştür. Batı'da işlevselliği nedeniyle bir zanaat olarak görülmüş, majör sanatlar arasında sayılmamıştır. ${ }^{10}$ Uzakdoğu ve Anadolu'da ise her zaman özgün bir sanat olarak, kültürel sorumlulukları da içererek yaşamıştır (Galatalı, 2985:69). Pratik nedenlere dayalı, fonksiyon amaçlı el sanatları, binlerce yıl geçse de aynı kalabilmektedir. Bugün de hâlâ Anadolu kadını, seramiği ilk ortaya çıktığı hali ile (tornasız, fırınsız) üretmektedir (Güner, 1988:6).

Kolektif bilincin yaratıları olan zanaatta -el sanatlarındasanatçı özgünlüğü aranmaz. Sanat ile arasındaki en büyük fark özgün yaratıcılığın olup olmaması meselesidir. Batı'da mimari ve ona bağlı gelişen resim ve heykel, majör sanatlar sayılırken, seramik minör sanatlar arasında sayılmıştır. Zanaatta bireysel sanatçı arayış ve buluşlarına yer verilmemesi sorunu, yaratıcılığın engellenmesi olarak düşünüldüğünden modernizmde kabul görmemiştir. Ortaçağın sonlarında Batı sanatında birey yeniden doğmuştur. ${ }^{11}$ Sınıflandırmalardan kurtulmuş, geleneklerden sıyrılmış, hatta toplumsal zorunlulukları aşmış bir birey fikri modernitenin yükselişine dair bilgilerin de anahtarıdır (Todorov, vd., 1995:7). Modern insan, benzersizleşme, insanlığa dair bir işaret olarak görüldüğünde doğar (Todorov, vd., 1995:63). Bu nedenle zanaattaki el işçiliğine dayalı üretim ve kolektif bilinç içeriği geçmiş zamanlara ait geleneği sürdürmek anlamına gelirken sanattaki sanatçı özgünlüğü ve bireysel (individual) bilinç içeriği modernlik anlamına gelir. Zanaat ile sanat arasında hiyerarşik bir fark gözetmeyen Doğu'da ise sanat yapmak zaten zanaat yapmak demek olduğundan geleneğin sürekliliği vardır. Bir gösterge olarak, dilimizdeki san'at kelimesinin sınâi yani endüstri kökünden gelmesi de işlev ile sanatın Doğu'da nasıl birbirinden ayrılamaz bir bütün olduğuna işaret eder (Koç, 2008:21).12
\end{abstract}

olduğu çağların renk ve desen zevki hakkında fikir edinebilmek bakımından bir zorunluluktur (Nissen, 2004:34).

10 Picasso'ya kadar da "tamamlanmış bir geçmişin zaferlerini yeniden kullanan sanatçıların sanatı olarak" görülmüştür (Cumhuriyet, 1997:11).

11 Ortaçă̆ Batı dünyasından sonra yeniden... Antik Çă̆ kolektif bilincinde Firavun kültü, Imparator kültü gibi sanatçısının anonim olduğu uygarlıklara rağmen ve Hiyeratik Uygarlıklarda mimar isimleri geçer. Antik Yunan'da heykeltıraşlar şöhretlidir. Ancak Hıristiyan Ortaçağ'da birey olarak sanatçının bir önemi olmadığı gibi kolektif bilinç yaşanır. Individualizm ancak Rönesans'ta, Antikitenin uyanışı ile yeniden doğmuştur.

12 Sanat - zanaat tartışmalarına bir yanıt olarak İslam estetik felsefesi gösterilebilir: İslam estetiği sanattaki özgünlük sorununun yeterince anlaşılamadığını savunur. Buna göre yaratış anı bitmemiş; devam etmektedir. Her an yeni bir yaratış anıdır, tecrübe de her an biricik olduğundan hakiki sanat eseri her türlü tezahüründe biricik olma özelliğini korur (Koç, 2008:44-45). Yeterince anlaşılamayan nokta, İslam estetiğindeki tercih meselesidir: dünyadaki çokluğu ve değişkenliği, dünyevi olanı tenzih eden (dışta bırakan) görüş, sanatı belirli sınırlar içerisinde hareket edilebilecek bir alana çektiğinden, bize, çıkan sonuçlar aynıymış gibi görünür. Gerçekte olan, kişiselıiğini devre dışı bırakan sanatkârın, üretimlerinde asıl kendisinin ortaya çıkışıdır. Sufizmdeki bireyin ölüşünün, özgünlüğün yitişi olarak yanlış anlaşıldığını söyleyen Prof. Kemal Sayar'a göre, "Sufizm bir yeniden doğuş sanatıdır, bir kimsenin doğalıı̆̆ını yeniden kazanma sürecidir, tekdüzeliği aşma yoludur ve yaratıcı vizyon aracıdır (2004:46). Kişinin nefsi öldükten sonra ortaya çıkan, bir parmak izi gibi özgün olan kendi özüdür çünkü. Worringer'e göre ise, Doğu kültür ve sanatının hızla dinsel ilgi kurmasının altında yatan neden insanın dünyada diğerleri gibi bir ölümlü olma korkusundan ötürü transandant olana sığınma ihtiyacını hissedişidir. Buradan soyut dekorasyon bezemeciliği doğmuştur. Sanat kolektif bilincin ürünü olan zanaata dönüşür $(1985: 23-24)$. 
René Guénon modern dünyanın bunalımının Rönesans'taki bireycilik fikrinden doğduğu konusunda Burckhardt ile aynı fikirleri paylaşır (1999:90-92). 20. yüzyıl Bauhaus ekolü ise bireyciliğin aşılması meselesinde Hakikat boyutunu savunan gelenekselcilere alternatif olarak yeni bir dünya düzeninden bahsederler. W. Gropius'a göre: "Mimarlar, ressamlar, yontucular hepimiz zenaata geri dönmeliyiz. Çünkü sanat meslek değildir. Sanatçıyla zenaatçı arasında öz ayrılığı yoktur. Zenaatçının güçlüsüne sanatçı denir" (İpşiroğlu, 1993:138). Ne var ki endüstri toplumuna inanan toplumcuların, endüstrinin insanlığın mutlak mutluluğunu getireceğine dair şaşmaz inançları günümüzde asılsız çıkmıştır.

Picasso örneğinde, modern Batılı bir sanatçının kişisel üslubunu oluştururken Doğu kolektivizminden beslenmesine tanık oluruz. Batı'nın Doğu'dan etkilenmesi ilk defa Yirminci Yüzyılda olmamıştır; tüm etkileşimlerin beşiğinde ticari alışveriş yattığı gibi 15. yüzyılda da Batı'da çömlekçilik endüstrisi kurulurken Doğu'dan bilgi transferi yapılmıştır. İtalyan Rönesans kültürü dünya çapında bir seramikçiliği hızla geliştirirken dahi İslam Sanatı, Çin porselenleri ve İznik çiniciliğinden hem fikir, hem motif devşirmeyi sürdürmüştür (Mack, 2005:158). On sekizinci yüzyılda Chinoiserie, Turquerie oryantalist modalarının ardından, 19. yüzyıl Romantizm Akımında da uzak, "egzotik" diyarlara doğru bir çekilim yaşanmıştır (Germaner, 1996:58-71). Bu etkiyi, İzlenimcilerin ve İzlenimcilik sonrası ressamların Japon baskı sanatı ilgileri izlemiştir. Batı için "Doğu"nun13 kültür ve sanatı, kendinden memnun olmadığı anda, sanatçı ve düşünürlerinde ortaya çıkmıştır. Bu ilgiyi J.J. Rousseaucu Dekadanlık felsefesi ile birlikte ele almak gerektir. Avrupa içinde liberal ekonomi düzeni ve sanayi toplumuna geçişle yaşanan insan ve doğa hakları ihlallerine tepki olarak gelişen çöküş edebiyatı özetle Batılılık kültürünün kendisinden şüphe duymasıdır. Sanatçıların ve entelektüel çevrelerin yüzünü "Doğu" kültür ve sanatına çevirmeleri gerçekte kendi kendilerini eleştirileridir. Bozulmamış Doğu'nun keşfi, sanatçılar açısından "kaynağa dönüş"ü ifade etmiştir.

Primitif değerlerin, modernleşen seramik sanatında ortaya çıkışı ilk defa Picasso ile olmamıştır. Aynı zamanda bir ressam olan Rene Buthaud (1886-1987) ve Jean Mayodon (1893-1967) Grek, Pers ve Doğu seramiklerinden esinlenerek primitif ve klasik öğeleri kaplar üzerine resmetmiş Art-Deco sanatçılarıdır (Hood, 2013:1). Mayodon'un ilgisi özellikle Antik Yunan vazo betimlemelerine odaklıdır. Günümüze kalmış resimli Yunan Antik vazolarının nitelik ve niceliği düşünüldüğünde sanatçıların ilhamı kolaylıkla anlaşılır. Gördüğünü alıp kendine mal etme konusunda büyük beceriye sahip Picasso'nun gerek Antikite'nin, gerekse yeni üretimlerin etkisinde kalmış olabileceğini hayal etmek zor değil. Bununla birlikte Picasso'nun görmesi ile diğer sanatçıların bakışında temelde bir ayrım yatar. Konusu ile ilgili olarak daima kavramsal düşünebilme yetisine sahip Picasso, seramik kaplarda en eski fakat yeni bir şeyi keşfeder. O, kapları resimlemez, kabın formunda gizli olan figürleri açığa çıkartır (Görsel 3). Çift yönlü ilerleyen bu üretimde form, resmi; resim de formu almaşık olarak doğurur. Resim, seramiğe sonradan eklenen bir öğe olarak düşünülmez; seramiğin kendisinden türer (Görsel 4 ve 5).

\footnotetext{
13 Coğrafi yönleri işaret etmez. Avrupa ve ABD Batı, dışında kalan her yer, onlara göre, Doğu'dur. Doğu kavramının içine ötekileştirilenler girer.
} 


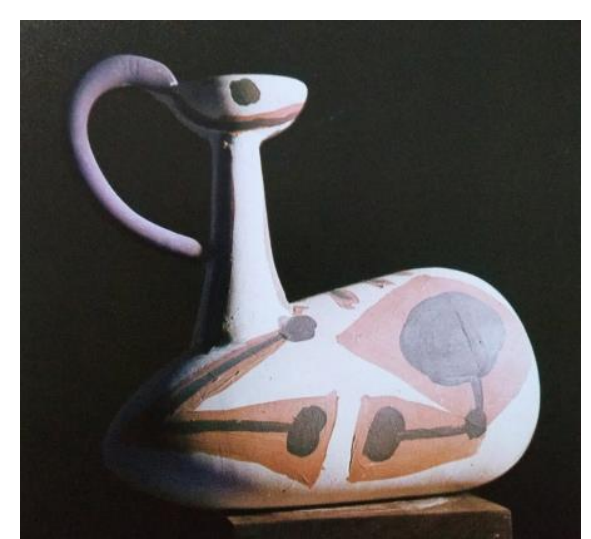

Görsel 3. Picasso 1947

$32 \times 15 \times 28 \mathrm{~cm}$. Picasso Müzesi, Antibes

(Visual 3. Picasso Museum)

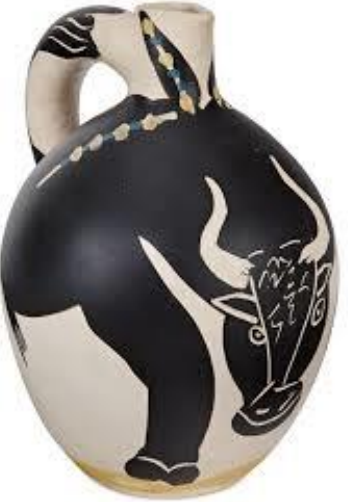

Görsel 4. Picasso "Boğa", 1955, $32 \mathrm{~cm} \times 25 \mathrm{~cm}$

(Visual 4. Bull)

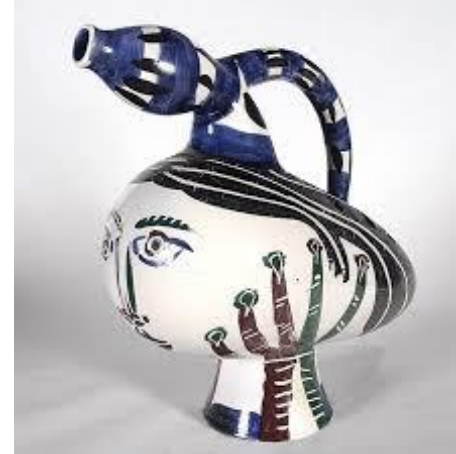

Görsel 5. Picasso, 1951, "Ördek Çiçeklik"

(Visual 5. Duck Flower-Holder)

Seramikte yaratım anı, görme ile ilgili olarak çok önemli olduğundan baştaki tasarımdan farklılaşabilir. Bu üretim şeklinde görme yetimiz en uç seviyesindedir. Algı ruh bilimine göre ışığın ve renklerin haricinde şeylere dair bilginin hiçbiri sadece görme duyumu ile elde edilemez. Üç boyutlu uzama dair bilgilerimizi dokunma duyumu ve devinim aracılığıyla ediniriz. Bu nedenle elle yoğrularak, bedenin devinimi ile oluşan üç boyutlu tasarımlar, görme duyumundan daha nesnel veriler sağlarlar (Gombrich, 1992:29-32). Seramikteki buluş̧uluk da devinim sırasındaki oyun ile kurulur. İmge oluşturmanın büyüsüne kapılan zihin devinim sırasında son derece aktiftir. Bir an için oluşan imge ufak bir ek ile bambaşka bir imgeye durmaksızın dönüşür (Gombrich, 1992:22). Motivasyonu sağlayan da biçimdeki sürekli değişimin yarattığı şaşkınlıktır. ${ }^{14} \mathrm{Bu}$ anlamda kararıı olmayan bir sanatçı için avantaj gibi görünen yaratım anı, hedefsiz bir dizginsizlikte dezavantaja dönüşebilir. Picasso'nun seramiklerinde kontrollü bir oyunu izleriz. Bize söylediği daima onun bir kap olduğu vurgusunun akılda tutulduğudur. Yaratıcısının Madoura standındaki ilk karşılaşma heyecanını durmaksızın iletir. Picasso, üç boyutlu başka bir sanat dalından, örneğin heykel sanatından etkilenerek onu dönüştürmemiştir. Seramik geleneğine dair zanaatçılıktan etkilenmiştir. Üretirken aklından çıkartmadığı, onu bu yola sürükleyen, ilk karşılaşmasındaki etkidir. Bu nedenle Picasso seramiklerinde topraktan gelen geleneğe, coğrafyaya, doğaya, saygı süreklidir. Insanoğlu kendini bildiğinden beri toprakladır. Yaşayan, yaşatan, ürün veren toprak, sanatçılar için vazgeçilmezdir. Binlerce yıldan beri üretilen seramik; yeryüzünün hemen her yerinde bulunan kilin, insan elinde şekillendirilerek pişirilmesi ile yaşamın doğal bir parçasıdır. Bu nedenle insan-doğa ilişkisi içerisinde genel kuralları bakımından evrensel bir dile sahiptir (Tizgöl, 2008:129). Picasso toprağa saygıyla yaklaşmış; toprağın nefes aldığını hissetmiştir (Çil, 1997:11).

"Bu sevda onu yaz tatilinden mahrum etmiş; bu yolun azimli bir işçisine dönüştürmüştür. Toprak ve ateşin gizemine dalmış; toprağa saygı ile yaklaşmıştır. Başparmağın sadece küçük bir darbesine karşı çok hassas, ayrıca nemdeki en ufak değişimlere

\footnotetext{
14 Eski Yunanlılar, şaşkınlık duymanın bilmenin başlangıcı olduğunu ve artık şaşırmadığımızda, bilgimizi yitirme tehlikesiyle karşılaştığımızı söylerlerdi (Gombrich, $1992: 23)$.
} 


\begin{abstract}
karşı tepki veren bu malzeme anlayışsız ellerde ne denli inatçı ise ona saygı ile yaklaşan ellerde o denli uysaldır. Gerçekte bu malzemenin kıymeti, alçak gönüllü kalıcılığı ile insanlık mesajının en gerçek taşıyıcısı olmasındandır. Taş oymalar toz ve aşınma ile ufalanırken, metal dökümler paslanarak toz haline gelirken, fırınlanmış küçük kil tabletler üzerlerindeki grafik izleri ile günümüze kadar ulaşabilmiştir. Picasso tüm bunları biliyordu. Bununla beraber bu sade zanaatın tüm zorunlulukları, tüm belirsizlikleri ve tüm kararsızlıkları ile yüzleşti. Diğer taraftan malzemenin muhteşemliğiyle, sürprizlerini açığa vurmasıyla büyülendi. Malzemenin doğasına boyun eğerek, onun önerilerini kabul etti" (Ramie, 1985:7).
\end{abstract}

Herbert Read The Origins of Form in Art adlı eserinde kullanım amaçlı nesne gelişimini üç kısımda inceler:

- İşlevsel biçimin bulunuşu;

- İşlevsel biçimin maksimum etkinliğe ulaştırılması;

- İşlevsel biçimin serbest ya da sembolik olma yönünden gelişimi (akt. Çil, 2008 :2).

İ̧ boşluk yaratma gereksinimden doğan çömlek formu üçüncü aşamasında sembolik bir değer kazanmıştır. Kanadalı seramik sanatçısı Methieu'ya göre alan değerlendirme, sanatların özüdür. Resim iki boyutlu bir alanın araştırmasıdır; heykel, üç boyutlu alanın; mimari, içinde yaşadığımız tüm alanların; müzik, ses ve sessizlik arasındaki alanın; dans, hareket ve hareketsizlik alanlarının birer araştırmasıdır. Seramik sanatı da iki kenar arasındaki alanın, yani kabın iç boşluğunun araştırılmasıdır. Kabın üçüncü boyuttaki ve kavramsal boyuttaki boşluğu bu sanatın mihenk taşıdır (Çil, 2008:5). Seramik bir eser, kullanıma açık iç boşluk ile kapladığı alan olan dış boşluk arasında yer alan balçık kilinin sanatkârane şekillendirilmesidir (Galatalı, 1985:69). "Kap kullanım olgusu, seramik sanatında amaç olarak seramiği kap olarak somutlaştıran değerdir. Bu kullanım değerinin bağlantısındaki iç boşluk, yani hacim, seramik sanatında Öz'dür" (Galatalı, 1985:70). Bazı durumlarda sanatçı, işlevi reddetmeden onu aşar, bazen de kabın kullanım yönünü reddederek nesneye yeni bir işlev kazandırır. Biçimin içindeki alan, betimleyici olduğu kadar kavramsal bir alan olarak da algllanabilir.

Sanat iç dünyamızda metaforlar yarattığı için sanattır. Seramik sanatında hem bir kabı hem de yaşama dair form çağrışımlarını buluruz. Philip Rawson'a göre seramiğin kullanılır olmasının yanı sıra metaforik bir yönü de vardır. Birçok kap, içerisinde bir şey tutma işlevinden daha fazlasını ifade eder (Çil, 2008:6). Picasso seramiğe, günlük hayatta kullanılan tabak, kâse, vazo gibi formları renklendirerek, onları birkaç fırça darbesiyle geleneksel ve fonksiyonel bir objeden, resme dönüşüren çalışmalar yaparak başlamıştır (Çil, 1997:10) (Görsel 6). Günlük kullanıma sunulan parçaları kullanarak, bunların formlarında, umulmadık düşsel figürlere dönüşmelerini sağlayacak olanaklar bulmuştur (Çil, 1997:11). Kabın kap olma özelliğine gönderme yapan iç boşluğu korurken başka bir şeye dönüştürür. Seramik kabın içerisindeki iç boşluğu sanatsal materyal olarak kullanması, sanatının en ayırt edici özelliğidir. Bu özelliği ile kap geleneğine gönderme yapan yapıtları, toprağı sadece malzeme olarak değerlendiren seramik heykellerden ayrılır. Galatalı'ya göre klasik-modern sentezci yaklaşımda sanatçının eserdeki kullanımı dışlaması gerekir. İç boşluk dışlanmamasına rağmen bağlantısındaki amacı olan kullanım dışlandığında seramikteki öz nitelik korunmuş olur (Galatalı, 1985:72). 


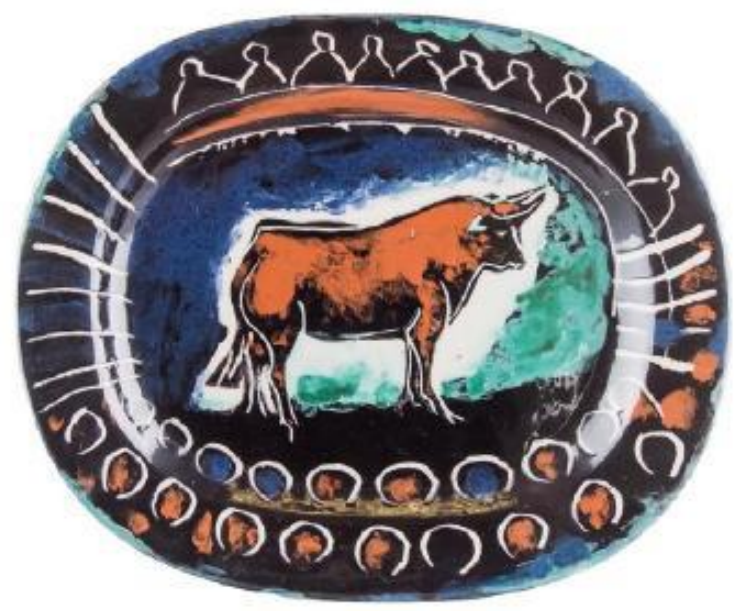

Görsel 6. Picasso, "Arenadaki Boğa", 1948, Shepparton Sanat Müzesi

(Visual 6. Picasso, "Bull in an Arena", Shepparton Art Museum)

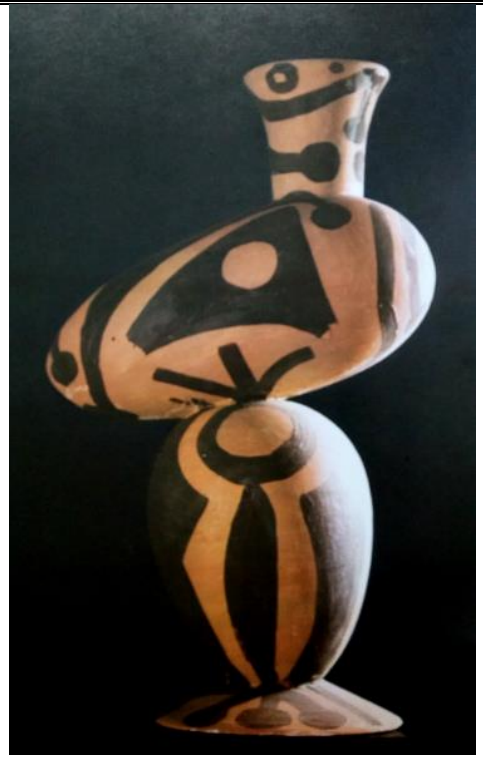

Görsel 7. Picasso," Formu İçerisinde Dört Element", 1947, Antibes Picasso (Visual 7. Picasso, "Four Element in the Form of a Bird", Antibes Picasso Museum)

"Seramik bünyeler üzerinde uygulanan dekorun temel amacı; formun şeklini zenginleştirerek ona yeni ifade olanakları sunmaktır. Seramik formlar üzerinde yapılan dekor tasarımları ve uygulamaları ne kadar formun bir parçası konumunda ise, bu durum uygulayıcısının o kadar başarılı olduğu anlamına gelmektedir" (Çevik, 2010:36). Picasso, parçaları orijinal forma göre boyayarak, forma tamamen farklı bir tanım getirmiştir. Bu şekilde formun belirleyiciliğini farklı bir boyuta taşımıştır. Onun fırçasında resim ve form birbirini tamamlar. Kilden küçük heykelcikler yaptığı zamanlar hariç, her zaman geleneksel çömlek formlarına bağlı kalmıştır (Çil, 1997:11). Kabın içindeki gizli metaforları gördüğünden seramik sanatının özünü de hissetmiştir. Picasso Madoura atölyesi üretimleri ile ilk karşılaştığında kapların içerisindeki gizli figürleri gördüğü için heyecanlanarak bu işe girişmiş olmalıdır. Kimi zaman bir seramik işliğinde defolu olarak çıkan ve atık malzeme statüsünde olan formları ekleyerek oluşturduğu figürleri, onun görsel algı heyecanını formlardan aldığının kanıtlarından biridir (Görsel 7). Fakat onu asıl etkileyen, seramiğin doğal yapısı olmuştur.

Ressamları seramik çalışmaya yönlendiren dürtü üçüncü boyuta ulaşma istekleridir. Picasso bu dürtüsünü tatmin için, çok güçlü, ready-made ekolünü yaratmış, bir heykel diline sahipti. Heykel de üretmiş, form nedir iyi bilen bir Paris bohemine göre amaç sadece form olmasa gerektir. Onun bu Akdeniz kasabasında bağlandığı, gelenekselin kendi çă̆ına yansımış son ucunu hissedişi olmalıdır. Picasso'nun farklı yaklaşımı primitife dışarıdan bir bakış değil; onu içeriden algılayıştır. Bu önemli fark, primitiften esinlenme ile onu içeriden duyuş arasındaki fark kadar keskindir. Herbert Read'e göre seramik, sanatların hem en zoru (soyut olduğu için), hem de en ilkelidir. En ilkeldir çünkü en basittir (İnan, 2018:11). Picasso'nun ilkelliği keşfi seramik ile olmamıştır. Afrika masklarından yola çıkarak Kübizmi inşa etmiştir. Primitif büyü mantığı ile işleyen zekasına en iyi örnek, nesneleri dönüştürerek canlandırdığı, modern sanatın kendisine 
borçlu olduğu, ready-made kavramının mucidi oluşudur. Onu seramik yaparken izleyen Roland Penose'un tanıklığı aşağıdaki gibidir:

"Önce boynu burdu, böylece vazonun gövdesi, balon gibi şişerek bu dokunuşa tepki gösterdi; sonra, hünerli birkaç kıvırma ve sıkmayla kullanım nesnesini, hafif, kırılgan ve yaşam soluyan bir güvercine dönüştürdü. "Görüyorsun ya," dedi, "güvercin yapmak için önce boynunu burmak gerek" (Berger, 1992:108).

Buradaki aktarım bu işin büyüsel bir etkileyiciliği olduğu vurgusudur; güvercin nefes almıştır. Bir anda değişen form çocukça bir oyunun, ilkel büyünün eseridir. Bir başka tanıklık Madoura Atölyesi'nde onu çalışırken izleyen seramikçi Georges Ramie'ye ait olanıdır:

"Ínsan ondan gizemli bir akım geçtiğini hissedebilir. Karşı konulamaz bir güç eşliğinde gelen ve derhal uyulması gereken ani bir dizi belirsiz etkiyi tamamen tatmin etmek gerekir. Onun üzerinde hakim olan bu iç güç, bu bastırılamayan susuzluğu yatıştırarak, yaratıcılıktaki ilerleyişini hızlandırmıştır" $(1985: 8)$.

Modernin tanımındaki akılcılık unsuru ile 20. yüzyıl modern sanatçılarının büyü ve ilkelden etkilenmiş olmaları gerçeği birbiri ile örtüşmez.

"Sanat nesnesi dediğimiz şey özerk bir nesne olarak Modernizme özgüdür. Daha öncesinde ise öte dünyadan söz eden dinsel, büyüsel bir anlatımdır. Kapitalist üretimle birlikte sanat dinden ayrılmış özerklik kazanmıştır. Rönesans'a erişinceye kadar nesne gerçeğinin yeri simgelerle dolmuş, fakat Yenidendoğuş'la birlikte bunun yerini matematiksel bir nesne almıştır. Artık nesne somuttur, aklın uzantısıdır. O çözümlenebilir, irdelenebilir, sorgulanabilir; yalnızca doğayı taklit etmeyecek, modelle özdeşleşmeyi aşacaktır" (Şen, 2004: 18)

Seramiğin kap ve figürin gibi başlıca form tipleri ile pagan geleneğe bağlı oluşu; çok fazla anlam yüklü ve domestik oluşu; geçmişe dair çok fazla ilişki çağrıştırması Modernizmin ilerici bakış açısı ile örtüşmez (Tizgöl, 2008:100). Modern sanatın ideolojik temeli olan Modernizm, değişim ve ilerlemeye öncelik verir. Sanatçıların özellikle klasik ve geleneksel anlatım biçimlerinden koparak gerçekleştirdiği yöntemler, tarzlar ve tavırlar bütününü tanımlar (Tizgöl, 2008:78). Bu tanımlamalara göre Modern Çağda seramiğin işlevselliğini bozarak onu kişisel bir ifade aracına dönüştüren Picasso'nun yenilikçiliği onu modern yapmaya yetmez, çünkü üretiminin diğer cephesi, geleneksele dönüş vurgusudur. Ancak modernin tanımındaki avant-garde fikri Picasso için uygundur. Buna göre bir sanatçı doğayı eskimiş kurallara göre değil, çağın gereklerine göre yorumlar ve ayrıca bilinmeyeni keşfe çıkar, risk alır (Yılmaz, 2005:17). Picasso yaşadığı çağın tanığı olarak Avrupa'nın kendisini var eden kurallarının eskidiğinin farkındaydı. Çă̆, ötekileştirilmiş olana, akıldışı olana, çocuksu saflığa, çılgınlık ve kendini bırakışa ihtiyaç duyuyordu. Böylece 20. yüzyıl Modernizmi içerisindeki avant-gardist oluşum, ilerlemeci tarih anlayışına indirilen güçlü bir darbeydi. "Çağın Gereği"nin Primitivizme dönüş olduğunu daha en başından sezinleyen Picasso'nun yeniyi kurmak için geriye yönelişini tartışmak, onun modern, postmodern ya da başka bir şey olmasını tartışmaktan daha önceliklidir. Bu sorun Batılılık kimliğinin ne olduğu ile ilgilidir.

\section{SONUÇ VE ÖNERILER (CONCLUSION AND RECOMMENDATIONS)}

Picasso'yu çağdaşı diğer seramik üreten modernlerden, geleneksel Akdeniz seramik zanaatından beslenen yönü dolayısıyla, ayrı bir konumda incelemek gerekir. Picasso'yu çağdaşı seramik üreten ressamlardan ayıran en belirgin özelliği, seramikler üzerindeki resimlerinin ilhamını, seramik kabın formundan almasıdır. Kabın 


\begin{abstract}
formuna öncelik vermesi ile, geleneksel seramik dilini, çağdaşlarına göre daha iyi kavramış olduğunu söyleyebiliriz. Gelenek ile moderni sentezleyen anlayışında diğer soyut, heykel ya da kavramsal seramik üretimlerinden ayrılan en belirgin özelliği işlevsel iç boşluğun korunması fakat bu boşluğun işe yaramaz bir noktaya çekilmesidir. "Bu noktada önemli olan, bir çömlek yorumlanırken iç boşluk bulunmasına rağmen iç boşluğun bağlantısındaki kullanım öz'ünün dışlanmış olmasıdır" (Galatalı, 1985:96).

Picasso'nun, resimleri için form aradığını iddia edemeyiz, çünkü sanatçı Madoura Atölyesi'nden önce de üç boyut ile ilgilenmiş, pek çok heykel gerçekleştirmiştir. Ama o'nun, resimlerini üç boyutlu gördüğünü söyleyebiliriz. Picasso seramik geleneğinin en primitif hali ile bir kap sanatı olduğu gerçeğini daima hatırlatır. O, seramikleri resimlememiştir. Seramik formlar içerisinde saklı duran figür anıştırmalarını fark etmiştir. İlhamını seramiğin kendi formundan alarak, onlarda gördüğü figürleri ortaya çıkartmıştır. Bu temel özellik bir kabın içerisinde gizlenmiş figürü fark eden Hititli sanatkârın tavrından farklı değildir (Görsel 2). Hitit eserlerindeki özgün formlardan nasıl haz duyuyorsak Picasso'nun eserleri karşısında da benzer coşkuya kapılırız. Akdeniz havzasında doğup gelişen seramik sanatının modern dile tercümesindeki bu başarı sanat konusunda önemli bir gerçeğe vurgu yapar: "çağdaş seramik sanatının tarihi gelişimi, günümüze ulaşan çeşitli kültürlerin sanatsal birikimi üzerine
\end{abstract} kuruludur (Avşar, 2015:97).

Sanatçı ömrünün son üretken döneminde de heyecanlarını bize aktarmada başarılı olmuştur. Bunu doğaya, toprağa, ilkele dönerek gerçekleştirmiştir. Sanayi devrimi, kapitalizm, sömürgecilik ve savaşlarla yorgun düşmüş Avrupa kültüründe bulamadığı değerleri Doğu'nun, el sanatlarının, ilkelıiğin, doğanın saflığında bulan bu olgun sanatçı ruhu, insanlığa önemli bir sanat dersi verirmişçesine arkadaşlarını, hobilerini, hatta fırçalarını bırakarak Paris'i terk etmiştir. İlk insanın büyü ayini olan ritüele geri dönmekle kibar dünyayı terk eder; anı yaşar; insan olmanın gereğini sanatla kurar. Sanatçı tavrı olarak, önem vermek açısından böylesi bir yatırımda bulunmuş olması; toprağa, doğaya, primitife karşı değerin yitip gittiği günümüzde de ayrıca anlamlıdır. Avrupa'nın savaşlarından geçmiş, yıkımı görmüş yaşamış yorgun ve yaşlı Avrupa'dan yorulmuş olgun bir sanatçının kendini ifade aracı olarak insanoğlunun en eski, en doğal ve yalın sanatını seçişi, doğada doğa ile üretimi bir rastlantıdan ötesidir fakat Batı dünyasına ve Çağına verilmiş bir yanıttı.

\title{
KAYNAKLAR (REFERENCES)
}

Ağatekin, M., (2002). Dünya'da ve Türkiye'de Çağdaş Seramik Sanatının Oluşum Süreci. earsiv.anadolu.edu.tr.

Alkan, D., (1999). Amerika'da Çağdaş Amerikan Sanatı.

earşiv.anadolu.edu.tr (Erişim:

https://earsiv.anadolu.edu.tr/xmlui/bitstream/handle/11421/1179/141 058 . pdf ? sequence=1\&isAllowed $=y)$.

Arcasoy, A., (1983). Seramik Teknolojisi. İstanbul: Marmara Üniversitesi Güzel Sanatlar Fakültesi Yayınları, SS:1-2.

Avşar, L. ve Avşar, M., (2015). Seramik Sanatı Eğitiminde Selçuklu Seramiğinin Yeri. Kalemişi Dergisi, 3(5):97-110.

Başgelen, N., (2006). Seramiğin Bulunup Geliştiği Anadolu'nun Benzersiz Dönemi Neolitik Çă̆. Seramik Türkiye Dergisi, sayı:13, ss: 109-120.

Bayazit, M. ve Işık, İ., (2012). Geçmişten Günümüze Çini Sanatı ve Kütahya Çiniciliği. Journal of Life Sciences, 1(1):891-898. 
Çevik, N., (2010). Çă̆daş Seramik Sanatında Resimsel Yönelimler. Sanat ve Tasarım Dergisi, $1(6): 35-45$.

Çil, S., (2 Mart 1997). Ve Toprak Picasso'nun Ellerinde. Cumhuriyet Dergi, sayı:571, ss:1-10,11,12.

Çil, S., (2008). Seramiğin Boşlukla Sınavı. 7. Uluslararası

Katılımlı Seramik Kongresi, Afyonkarahisar, ss:1-6.

Galatalı, A., (Mayıs 1985). Eleştirim. Sanat Çevresi Dergisi, (79):68-71.

Gombrich, E., (1992). Sanat ve Yanılsama. Istanbul: Remzi Kitabevi. Gökkaya, K.E., (2013). Disiplinler Arası Sanatsal İfade: Ressam Seramikçiler- Seramikçi Ressamlar. (24):25-40.

Guénon, R., (1999). Modern Dünyanın Bunalımı. İstanbul: Verka

Yayınları

Güner, G., (1988). Anadolu'da Yaşamakta Olan İlkel Çömlekçilik.

İstanbul: Akbank Ak Yayınları.

Hood, R., (2013). French Ceramic Excellence -Rene Buthaud, Jean

Mayodon. (Erişim: https://www.veniceclayartists.com/french-ceramicexcellence-rene-buthaud-jean-mayodon).

İnal, İ., (2006). 20. Yüzyılda Yeni İfade Arayışları ve Seramik Sanatı, Seramik Türkiye Dergisi, (13):106-113.

İnan, H.B., (2018). Seramik Form ve Yüzeylerde Resimsel Anlatımlar ve İmgeler. Yüksek Lisans Sanat Çalışması Raporu. Ankara: Hacettepe üniversitesi Güzel Sanatlar Enstitüsü Seramik Anasanat Dalı.

İpsiroğlu, N. ve İpşiroğlu, M., (1993). Sanatta Devrim. İstanbul: Hayalbaz Yayınevi.

Mack, E.R., (2005). Doğu Malı Batı Sanatı. İstanbul: Kitap

Yayınevi.

Mutlu, S., (2007). Zamanın Çarkında Anadolu'da Seramik. Anadolu Sanat Dergisi, (18):71-75.

Nissen, H.J., (2004), Ana Hatlarıyla Mezopotamya, Çev. Zühre

İkgelen, İstanbul: Arkeoloji ve Sanat Yayınları.

Özen, T.A., (1993). Ateşin Topră̆a Hükmettiği Sanat.

earsiv.anadolu.edu.tr (Erişim:

https://earsiv.anadolu.edu.tr/xmlui/bitstream/handle/11421/1070/987

58.pdf? sequence $=1$ \&isAl lowed $=y$ )

Ramie, G., (1985). Ceramics of Picasso. Barcelona: Ediciones

Poligrafa, S.A.

Sayar, K., (2004). Sufi Psikolojisi-Bilgeliğin Ruhu, Ruhun

Bilgeliği. 4.Basım, İstanbul: İnsan Yayınları.

Sözen, M. ve Tanyeli, U., (1992). Sanat Kavramları ve Terimleri

Sözlüğü, İstanbul: Remzi Kitabevi.

Şen, M., (2004). Sanat Nesnesi ve Mekan Arasındaki Zorunlu İlişki.

Yıldız Teknik Üniversitesi Sanat Tasarım Dergisi, (1):18-20.

Şölenay, E. ve Özer, G., (2013). Peter Osborne'nin Kavramsal Sanat Açılımı Doğrultusunda Çağdaş Seramik Sanatında Kavramsal

Çalışmaların İncelenmesi, Anadolu Üniv. Sanat ve Tasarım Dergisi, Ocak 2013 cilt:4, sayı:4, ss:33-52.

Tizgöl, K., (2008). Sanatta Minimalizm ve Günümüz Seramik Sanatına Yansımaları. İzmir: Dokuz Eylül Üniversitesi Güzel Sanatlar

Enstitüsü Seramik Anasanat Dalı Sanatta Yeterlik Tezi

Thomson, G., (1998). İnsanın Özü. (5. baskı). (çev. C. Üster).

İstanbul: Payel Yayınevi

Turani, A., (2007). Dünya Sanat Tarihi. 13. Basım, İstanbul Remzi Kitabevi Yayınları.

Uludağ, K.. (1997). Seramik Sanatının Kimlik Sorunu, earşiv.anadolu.edu.tr (Erişim:

https://earsiv.anadolu.edu.tr/xmlui/bitstream/handle/11421/1273/126 333. pdf ? sequence=1\&isAllowed=y). 


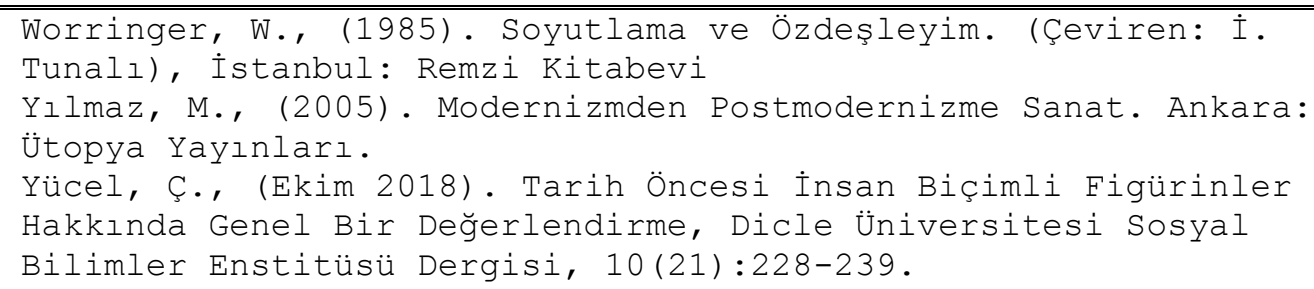

\section{GÖRSEL KAYNAKLAR (VISUAL REFERENCES)}

Görsel 1. Mezolitik Dönem pişmiş toprak İdol, Kahramanmaraş Direkli Mağarası (Yücel, Ç. (2018). Tarih Öncesi İnsan Biçimli Figürinler Hakkında Genel Bir Değerlendirme, Dicle Üniversitesi Sosyal Bilimler Enstitüsü Dergisi, $10(21): 239$.

Görsel 2. Hitit Uygarlığı Gaga Ağızlı Testi M.Ö.1700, Anadolu Medeniyetleri Müzesi.

Görsel 3. Pablo Picasso (1947). 32x15x28cm. Antibes Picasso Müzesi (Ramie, G. (1985). Ceramics of Picasso. Barcelona: Ediciones Poligrafa, S.A. ss:47).

Görsel 4. Pablo Picasso (1955). $32 \mathrm{~cm}$ x $25 \mathrm{~cm}$. "Boğa" (Erişim tarihi 01 Mart 2019). https://www. masterworksfineart.com/artists/pablopicasso/ceramic/taureau-bull-1955-2/id/W-6255

Görsel 5. Pablo Picasso (1951). 29x22x14cm. "Ördek Çiçeklik" (Erişim Tarihi: 01 Mart 2019). https: / / www.parkwestgallery.com/history-pablo-picasso-ceramics/ Görsel 6. Pablo Picasso (1948). "Arena'daki Boğa" (Erişim Tarihi: 01 Mart 2019). http://sheppartonartmuseum.com.au/eventdetails/!/488/event/picasso-clay-day Görsel 7. Pablo Picasso (1947). "Bir Kuş Formu İçerisinde Dört Element", $71 \times 18 \times 35 \mathrm{~cm}$. Antibes Picasso Müzesi (Ramie, G. (1985). Ceramics of Picasso. Barcelona: Ediciones Poligrafa, S.A. ss:46) 